Historical and zooarchaeological evidence of horn-working in post-medieval London

Yeomans, Lisa Marie

Published in:

Post-Medieval Archaeology

Publication date:

2008

Document version

Early version, also known as pre-print

Citation for published version (APA):

Yeomans, L. M. (2008). Historical and zooarchaeological evidence of horn-working in post-medieval London. Post-Medieval Archaeology, 42, 130-143. 


\title{
Historical and zooarchaeological evidence of horn-working in post-medieval London
}

\author{
By LISA YEOMANS
}

\begin{abstract}
SUMMARY: The 1641 list of members of the Horners' Company, parish registers and apprentice rolls provide information on the location of the horn-working industry in east London, on family relationships and on how horners' careers may have developed. Sawn cattle horncores distinguish horn-working deposits from butchers' and tanners' waste. Horn waste was used as a cheap substitute for brick to line pits in workshops of other trades and in houses and to line field drains in the nearby countryside.
\end{abstract}

\section{INTRODUCTION}

Horn is one of many raw materials obtainable from animal carcasses and was widely used to make artefacts in the post-medieval period, as it had been earlier. The economic importance of horn lay in its ready availability, in the variety of uses to which it could be put, and in its inexpensive manufacturing process. Its physical properties of malleability and translucency made it a useful material before the advent of plastics. ${ }^{1}$ As a cheap substitute for glass, it was frequently split into thin layers for lantern panes. In 1747 Campbell offered the following advice to parents seeking a suitable apprenticeship for their sons in horn-working, which had become a common urban industry:

It is none of the most polite Trades ... for the stench of the Horn, which they sometimes manufacture with the heat of the Fire, keeps them from the Hyp, Vapours, and Lowness of Spirits, the common Malady of England. ${ }^{2}$

Despite the importance of horn-working in the early modern period, detailed archaeological studies of the industry have rarely been published. ${ }^{3}$ In part this is due to the difficulty of recovering, studying and interpreting large assemblages of horncores. In his review of the London evidence,
Robertson agued that the faunal remains may have originated from such a wide area that the horncores would be uninformative about livestock brought into London. The London horners had trading privileges over all horn sold not only in London but also in much of the surrounding countryside. ${ }^{4}$ As age, sex and breed type of the cattle influence the size and shape of horncores, it is hard to deduce from them the type of cattle. Large accumulations of horncores can, however, testify to animal-carcass-processing industries and, when combined with historical evidence, the type of industry can be diagnosed. This paper examines documentary evidence of horn-working in order to further the interpretation of archaeological horncore deposits in London.

\section{HISTORICAL EVIDENCE OF HORN-WORKING IN POST-MEDIEVAL LONDON}

\section{LOCATION OF THE INDUSTRY}

The Lay Subsidy Rolls show that horn-working in the later Middle Ages was located in the west of the City and in the City parishes outside the western wall (Fig. 1). ${ }^{5}$ William le Pinour, the only horn-worker in the 1292 Roll, is called elsewhere 

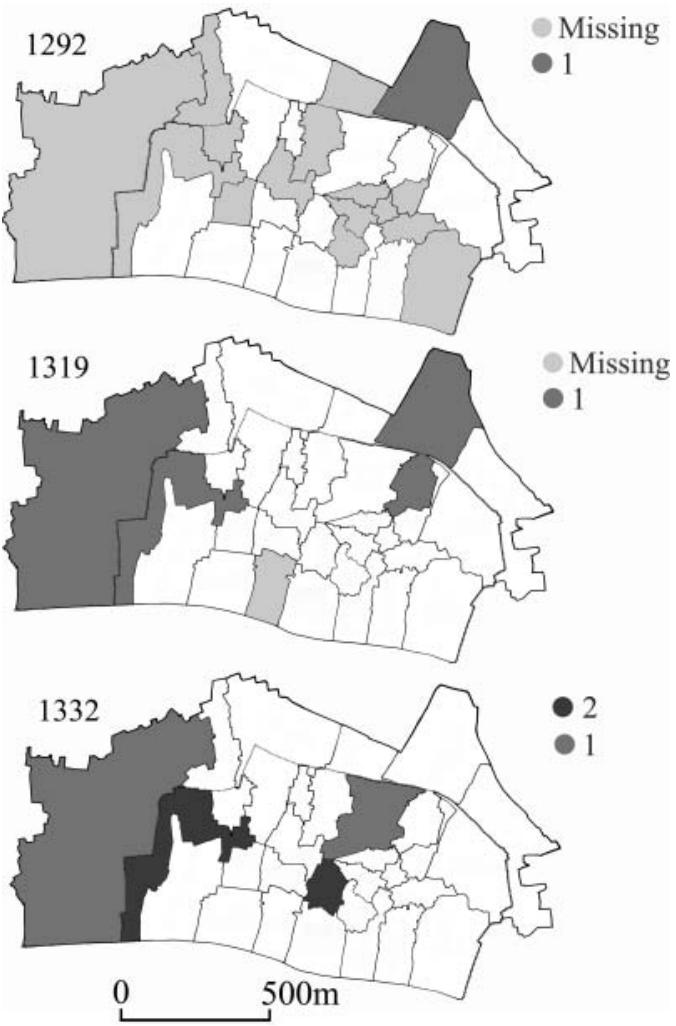

FIG. 1

Map of London: location of horners by ward according to the Lay Subsidy Rolls of 1292, 1319 and 1332 (data derived from Curtis 1918 and Ekwall 1951).

William le Horner. ${ }^{6}$ As pinour was probably an early form of pignour, Ekwall suggested that William was a maker of horn combs. ${ }^{7}$ As it is uncertain whether or not Gregory le B [...] ner (who may have been a botoner or button-maker), listed in the 1292 assessment of Cripplegate Within, worked in horn, he is not included in Fig. 1. Robert le Horner de Luddegate of Farringdon Within featured in both the 1319 and the 1332 rolls. ${ }^{8}$ The importance of Farringdon for horn-working may reflect the presence of tanners in the vicinity of the Fleet from whom the horners obtained their raw materials. Some horn-working was also undertaken further east.

The more substantial evidence for hornworking in the post-medieval period shows the industry in the same areas of the City, but indicates a shift towards the eastern parishes. Because of its unhygienic and pungent nature, horn-working was in 1455 prohibited within the City walls. In London the craft of horn-working was controlled by the Horners' Company, whose 1641 list of members is the best single source for the location of the industry (Table 1). Of 44 horners, 34 worked in 'Petticoate Lane', or Middlesex Street as it is also known. Three gave 'Fleete Streete' as their address, two listed 'Holbournebridge', one was from 'East Smythfield', one was located in Towerhill, and the last seems to have moved to Norwich. ${ }^{9}$

Petticoat Lane lies within the parishes of Whitechapel and St Botolph Aldgate and to a lesser extent of Spitalfields and of St Botolph Bishopsgate (Fig. 2). Place names of trades also indicate where, at least at some point, horn was worked. Inkhorn Court in St Botolph Aldgate and Horns Yard and Horn Yard in Whitechapel were within a short walk of Petticoat Lane.

Parish registers provide additional information of where the industry was practised. The St Botolph Aldgate baptism register from the later part of 1587 until 1664 often includes the father's occupation (Table 2) ${ }^{10}$ Since horners were recorded in some of the earliest entries, the industry was presumably already well established in the parish; it remained so throughout the period.

Many of the horners mentioned in the Aldgate parish register lived not only in Petticoat Lane but also in Houndsditch, Fire Ball Grounds, Gravel Lane, Mouse Alley, Woolpack Alley and Swan Alley. The 1641 list may only have recorded the approximate location of businesses instead of the small alleyways close by. For example, Thomas Lovejoy gave Petticoat Lane as his address in 1641, but, when his child was baptized in 1648, he lived in Woolpack Alley and remained there until at least 1660 .

As occupation was only stated consistently in the Whitechapel parish registers between 1650 and 1660 (Table 3), ${ }^{11}$ it is not known how long horners were present in the parish after 1660. Despite the limited chronological range of the registers, many horn-workers were recorded as residents of the parish.

Horners were not mentioned in the Spitalfields registers before the last quarter of the 17 th century (Table 4). ${ }^{12}$ A number of workshops appeared on different streets in the parish in a relatively short span of time. Fisher argued that the London horn industry would have gone into sharp decline around this time but for the demand for horn lantern panes for street lighting. ${ }^{13}$ This new demand may have stimulated the spread of the industry into Spitalfields. After a break between 1736 and 1758 when the parish registers do not list occupations, no further horners are recorded, which may reflect the decline of the industry. 
TABLE 1

Members of the London Horners' Company as listed in 1641

\begin{tabular}{llll}
\hline Name & Address & Name & Address \\
\hline William Holland & Petticoate Lane & Thomas Collet(*) & Petticoate Lane \\
Thomas White & Petticoate Lane & John Smith* & Petticoate Lane \\
Ellis Good & Petticoate Lane & Edward Bartrum* & Petticoate Lane \\
Robert Baker* & Petticoate Lane & Thomas Baker* & Petticoate Lane \\
Frauncis Tython & Holborne bridge & George Seaton & Petticoate Lane \\
Robert Dix & Petticoate Lane & William Barnes(*) & Petticoate Lane \\
Christopher Peele & Petticoate Lane & Richard Newett & Petticoate Lane \\
John Norbury* & Petticoate Lane & Richard Cook* & Petticoate Lane \\
William Cowett & Fleete Streete & William Collett* & Petticoate Lane \\
John Swift & Petticoate Lane & William Gallopire & Petticoate Lane \\
Henry Smith* & Petticoate Lane & Thomas Boulter & Petticoate Lane \\
Robert Wright & Petticoate Lane & Thomas Croxall & Petticoate Lane \\
Richard Harbert & Petticoate Lane & Clement Peeke & Petticoate Lane \\
Simon Hergest & Petticoate Lane & John Smith Junr & Towerhill \\
Mrs Shaw & Tower Street & Thomas Lovejoy* & Petticoate Lane \\
Mrs Walker & Towerhill & Roger Hall* & Petticoate Lane \\
Robert Butcher & Norwich & William Champion* & Petticoate Lane \\
John Green & Fleete Streete & John Sutton & Petticoate Lane \\
Micheal Man & Petticoate Lane & John Torring & Petticoate Lane \\
John Bailye & East Smythfield & Robert Dagges & Petticoate Lane \\
Samuel Smith* & Petticoate Lane & John Bedford & Fleete Streete \\
Thomas Comb & Petticoate Lane & Richard Norbury & Holbornebridge \\
\hline
\end{tabular}

* Also identified in parish registers.

(*) Same name in parish registers after 1641 (son?).

Source: Fisher 1936, 117-19.

The parish registers considered show that the 1641 list was complete. A few horners may have moved, such as Edward Bartrum, who gave his address as Petticoat Lane in 1641, but by 1642 was living in Wentworth Street (Table 4). The registers confirm the importance of Petticoat Lane and also show that horn-working was more widespread (which the archaeological evidence also demonstrates). Although the Boar's Head Yard off Petticoat Lane was used for horn-working by a number of horners, no evidence has been found of when horners worked in Horn Yard and Horners Yard, but the Whitechapel parish register records occupations in only one decade. Surprisingly horners were not restricted to the smaller yards and alleyways where the stench of horn manufacture was less likely to have afflicted passers-by.

In the 1641 list John Bedford, John Green and William Cowett were located in Fleet Street (Table 1), where late-medieval horners may have obtained their raw material from tanners. The parish registers of St Bride Fleet Street rarely record occupations except for the first few months of 1587 , when one horner (Thomas Atkyns) was mentioned. ${ }^{14}$

In the early modern period the centre of the tanning industry shifted south of the river to Southwark and Bermondsey. ${ }^{15}$ Although none had been listed in these areas in 1641, the few horners found amongst the tens of thousands of parish register entries examined show that horn-working was relatively insignificant: a horner in Bermondsey Street in the 1754 Bermondsey baptism register, ${ }^{16}$ one in the St Olave register in $1758^{17}$ and another in St John's in $1765 .{ }^{18}$ In the St George baptism register for 1702 a horn turner in Suffolk Street and a horner in Peter Street in the Mint confirm horn-working in the East End. ${ }^{19}$

\section{ORGANIZATION OF THE INDUSTRY}

The parish records show not only how some hornworkers' careers developed but also their family ties. A number progressed from horn-breaker to horner (Tables 2-3). The former presumably 

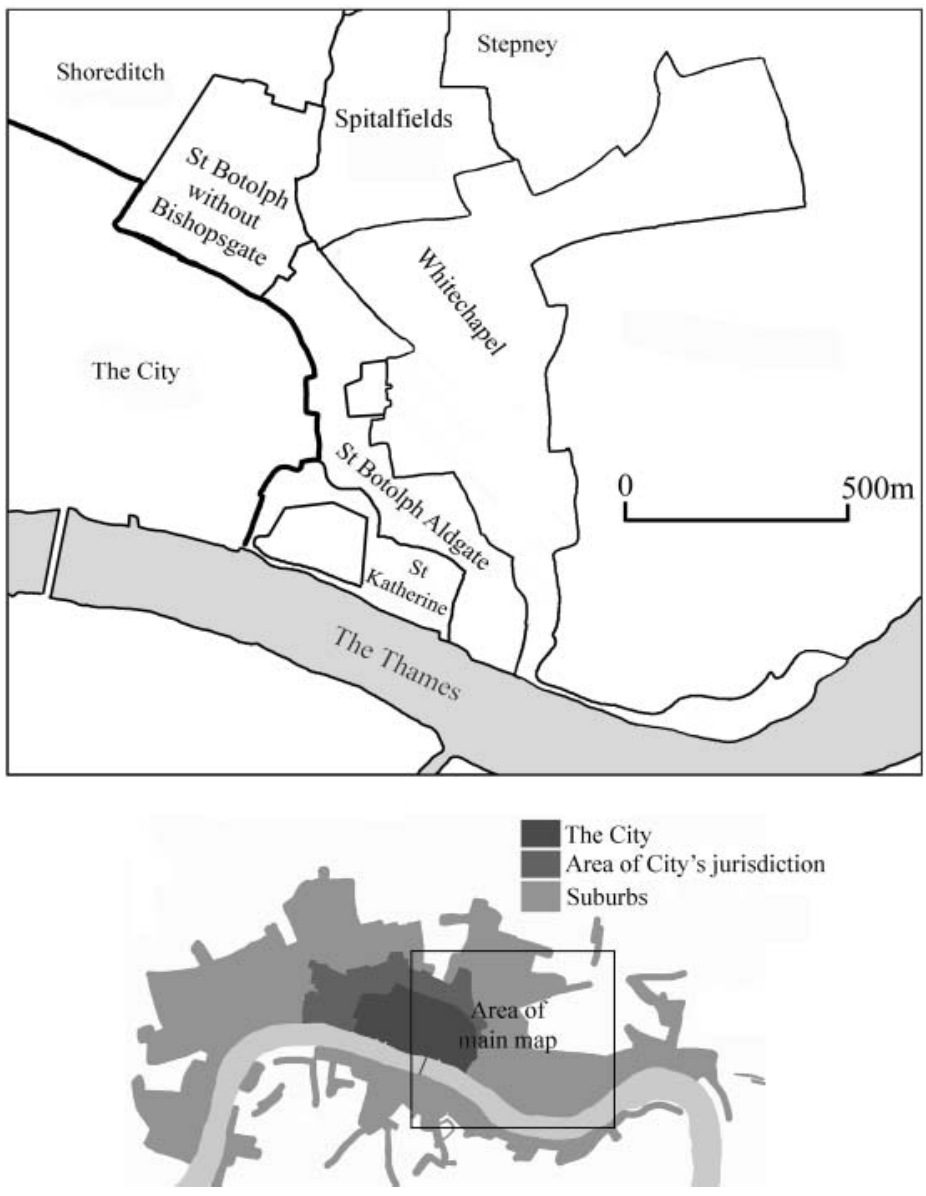

FIG. 2

Map of London, c. 1700: East End parishes where much of the post-medieval horn-working took place (after Brett-James 1935, fig. 6).

undertook the repugnant job of removing horn from the horncore, whereas horners probably engaged in more skilled tasks. For instance, Richard Peele, presumably a son of Christopher or Clement Peele, both members of the Horners' Company in 1641, worked as a horn-breaker in 1657 and progressed by 1659 to become a horner. William Million, recorded as a horn-breaker when he married at the age of 28 , had by the following year become a horner.

Not only could a horn-worker improve his status, he might also increase his wealth. To judge from the inventory of the horn-breaker John Addams's stock drawn up after his death in 1665, a substantial amount had been accumulated. His raw materials were stored in a shed, in the parlour, in the loft, in the house, in the cellar and in the workshop. ${ }^{20}$ John Norberry, also recorded as John Norburie, was sufficiently well off in 1655 to employ Jane Storkbridge as a household servant. ${ }^{21}$
By then he, if the records refer to the same individual, must have been one of the more experienced horners, having worked in the industry since at least 1619. At some point between 1619 and 1641 he moved from Houndsditch to Petticoat Lane, perhaps reflecting a rise in his fortunes (Tables 2-3).

Shared surnames suggest family relationships amongst horn-workers. John Dix (Table 3), who worked as a horner on Petticoat Lane, was probably the son of Robert Dix (Table 1). The Collet(t) horners may have fathered horn-breakers with the same names (Tables 1-2). Peter Rowland, the son of the horner Humphrey Rowland, was 25 years old and worked as a horn-breaker at the time his own child was baptized (Table 2).

That the craft of horn-working continued within families is shown in the apprenticeship lists. ${ }^{22}$ Almost a quarter of all horn-working apprentices, whose father's occupation was stated and who started training between 1731 and 1800, 
TABLE 2

London, parish of St Botolph Aldgate: horners and horn-breakers recorded in baptism register (B; 1558-1608; 1616-60) and in the 1641 Horners' Company list of members (H)

\section{Horners}

Thomas Hazell

Thomas Rowland

John Caborne

Humphrey Rowland

Robert Baker

John Norburie

James Baylie

Thomas Baker

William Collett

Thomas Lovejoy

Roger Hall

John Smith

Michael Milurn(?)

Simon Syaryutle(?)

Thomas Harris

Robert Danyes

John Cunen

Robert Mason

Alexander Ellerd

John Gray

Barnabie Joyne

Joshua Haolie

Thomas Howson
Residence

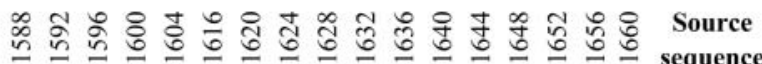

Covent Garden; then Petticoat Lane

Houndsditch; then Petticoat Lane

Aldgate; Petticoat Lane in 1641

Petticoat Lane

Petticoat Lane 1641; Woolpack Alley 1648

Petticoat Lane 1641; Whitechapel register 1656

Petticoat Lane

Petticoat Lane

Fire Ball Ground/Gravel Lane

Petticoat Lane

Gravel Lane

Mouse Alley

Petticoat Lane

Swan Alley

Petticoat Lane

Gravel Lane

Petticoat Lane

\section{B-B-B-B-B-B-B-B}
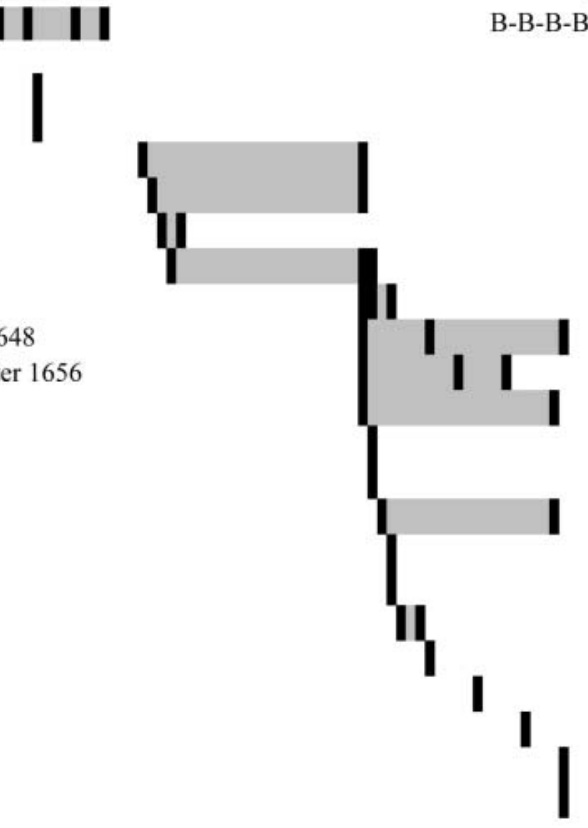

Horn-breakers who became horners

John Tarrant

Robert Dawkes

Horn-breakers

William Clenloe

James Mynen(?)

Robert Slam

Henry Turner

Thomas Dabony

John Dabony

Abraham Ash

Peter Rowland

William Barnes

William Holland

Robert Pully

Thomas Collett

Thomas Lobsion

John Simpson

William Drake

William Collett

Henry Smith
Gravel Lane; by 1656 horner on Petticoat Lane

Petticoat Lane

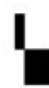

B

B-B-B

East Smithfield

Petticoat Lane

East Smithfield

Harrow Alley

Petticoat Lane

Woolpack Alley

Gravel Lane

Petticoat Lane

Petticoat Lane

Petticoat Lane

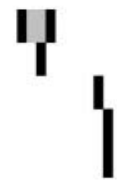

II

IIII

B-B-B-B
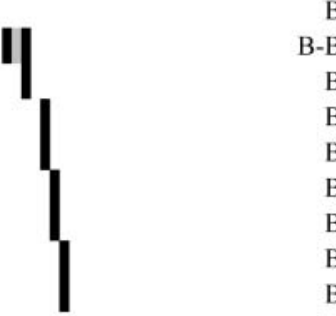

B-B

B

B

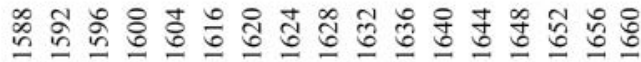

Black bar: year recorded.

Grey bar: presumed minimum working span.

Sources: baptisms, GL MS 9220, MS 9222/2; Horners' Company list, Fisher 1936, 117-19. 
TABLE 3

London, parish of Whitechapel: horners and horn-breakers recorded in parish registers (B: baptism 1655-60; D: death 1650-60; M: marriage 1655-60; R: death of relative or apprentice 1650-60), in 1641 Horners' Company list of members $(\mathrm{H})$ and in an inventory (I)

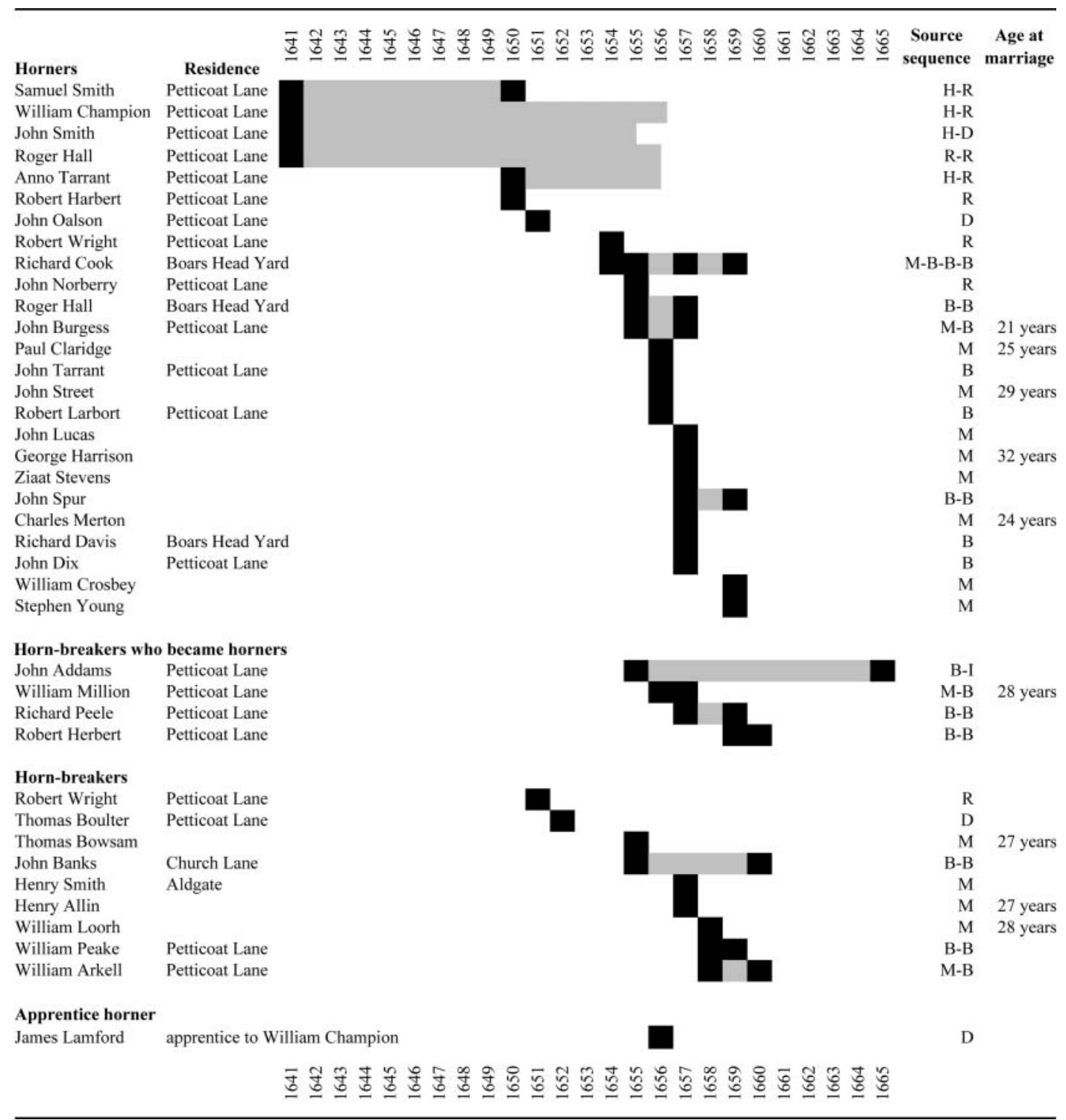

Black bar: year recorded.

Grey bar: presumed minimum working span.

Sources: baptisms, LMA P93/MRY1/002; burials, LMA P93/MRY1/058-9; marriages, LMA P93/MRY1/009; Horners' Company list, Fisher 1936, 117-19; inventory, Fisher 1936, 122-6. 
TABLE 4

London, parish of Spitalfields: horners and horn-breakers recorded in parish registers 1600-1728, 1765-1800 (B: baptism; D: death; R: death of relative or apprentice), and in 1641 Horners' Company list of members (H)

\begin{tabular}{|c|c|c|c|c|c|}
\hline Horners & Residence & 웅 & $\begin{array}{l}\mathscr{\varepsilon} \Sigma \\
\Sigma\end{array}$ & $\stackrel{\infty}{\infty}$ & $\begin{array}{l}\text { Source } \\
\text { sequence }\end{array}$ \\
\hline Edward Bartrum & $\begin{array}{l}\text { Petticoat Lane } 1641 \text {; } \\
\text { Wentworth Street } 1642\end{array}$ & & & & $\mathrm{H}-\mathrm{B}$ \\
\hline Richard Heath & & & & & D \\
\hline William Barrow & Brick Lane & & & & B-B-R \\
\hline George Horbrasher & Brick Lane & & & & B \\
\hline John Nalys & Thrall Street & & & & B \\
\hline Humprey Shale & Wentworth Street; then Brick & Lane & & & -B-B-B-B-B \\
\hline Samuel Phillips & Thrall Street & & & & B-B-B-B \\
\hline William Russell & & & & & R-R-R-B \\
\hline Benjamin Cordill & & & & & $\mathrm{R}$ \\
\hline Issac Stevens & & & & & D \\
\hline Richard Peak & Wentworth Street & & & & B \\
\hline William Stuchfields & Wentworth Street & & & & B-B \\
\hline Roger Ashbee & & & & & $\mathrm{R}$ \\
\hline Thomas Rodlye & Fashion Street & & & & R-B \\
\hline Abraham Green & Wentworth Street & & & & B \\
\hline John Brown & & & & & B-B \\
\hline Jonathon Addams & & & & & B-R-B-B \\
\hline William Deakins & & & & & R-B-B \\
\hline William Crawley & & & & & B-B \\
\hline John Huntingdon & & & & & B \\
\hline William Jackson & & & & & B-B \\
\hline Robert Norfolk & & & & & B-B \\
\hline Thomas Fisher & & & & & B \\
\hline Charles Howard & & & & & B \\
\hline George Clark & & & & & B \\
\hline John Askburnham & Wentworth Street & & & & B \\
\hline \multicolumn{6}{|l|}{ Horn-breakers } \\
\hline \multirow[t]{2}{*}{ Thomas Freeman } & Petticoat Lane & & & & B \\
\hline & $\underline{8}$ & 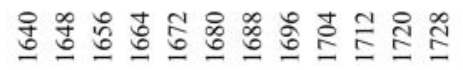 & $\stackrel{2}{2} \cong$ & $\stackrel{\infty}{\infty}$ & \\
\hline
\end{tabular}

Black bar: year recorded.

Grey bar: presumed minimum working span.

Sources: baptisms, LMA P93/DUN/255-60, P93/DUN/001, P93/CTC1/001-3; burials, LMA P93/DUN275-81, P93/DUN128-29, P93/CTC1/043-5; Horners' Company list, Fisher 1936, 117-19.

were the sons of horners (Table 5). Often they were not trained by their father but by another master horner. Surnames such as Adams, Leventhorp and Thompson recur in these lists, suggesting horners were a close-knit group.

At least some wives of master horners must have participated fully in the running of their husband's workshop. Widows often completed the training of apprentices and many took on new ones. A case of particular note is that of Mary Ann
Spratley, who after the death of her husband John Spratley oversaw the training of nine apprentice horners between 1748 and $1762 .{ }^{23}$

\section{DECLINE}

The Company of Horners ensured there was enough work for its members by regulating the admission of apprentices by masters. The fortunes of the industry can thus be deduced from the 
TABLE 5

Occupation of fathers of apprentices admitted to the London Horners' Company, 1731-1800.

\begin{tabular}{|c|c|c|c|c|c|}
\hline Apothecary & 1 & Framework knitter & 1 & Potter & 1 \\
\hline Barber & 3 & Gardener & 5 & Poulterer & 1 \\
\hline Bedstead-maker & 1 & Gent & 2 & Printer & 2 \\
\hline Blacksmith & 1 & Glover & 1 & Shopkeeper & 1 \\
\hline Brasier & 1 & Horn turner & 1 & Size-maker & 1 \\
\hline Bricklayer & 5 & Horner & 30 & Smith & 1 \\
\hline Broker & 1 & Hosier & 1 & Tailor & 4 \\
\hline Butcher & 1 & Husbandman & 1 & Tanner & 1 \\
\hline Carman & 1 & Joiner & 4 & Trunk-maker & 1 \\
\hline Carpenter & 2 & Labourer & 14 & Turner & 1 \\
\hline Clerk & 1 & Linen draper & 1 & Victualler & 1 \\
\hline Cloth-maker & 1 & Mariner & 3 & Vintner & 1 \\
\hline Coachman & 1 & Miller & 1 & Waterman & 1 \\
\hline Cooper & 2 & Packer & 1 & Weaver & 7 \\
\hline Cordwainer & 7 & Patten-maker & 1 & Wheelwright & 1 \\
\hline Farmer & 2 & Paviour & 1 & Yeoman & 2 \\
\hline Founder & 1 & Plumber & 1 & Total & 128 \\
\hline
\end{tabular}

Source: Webb 1997.

number of apprentices taken on each year (Fig. 3). ${ }^{24}$ In the 18th century the number of entries in many guild apprenticeship rolls fell, reflecting the decline of guild control; ${ }^{25}$ but the Horners' Company still commanded the industry in 1745 , when it successfully retained its right to be the sole producer of lantern panes. ${ }^{26}$ In the later

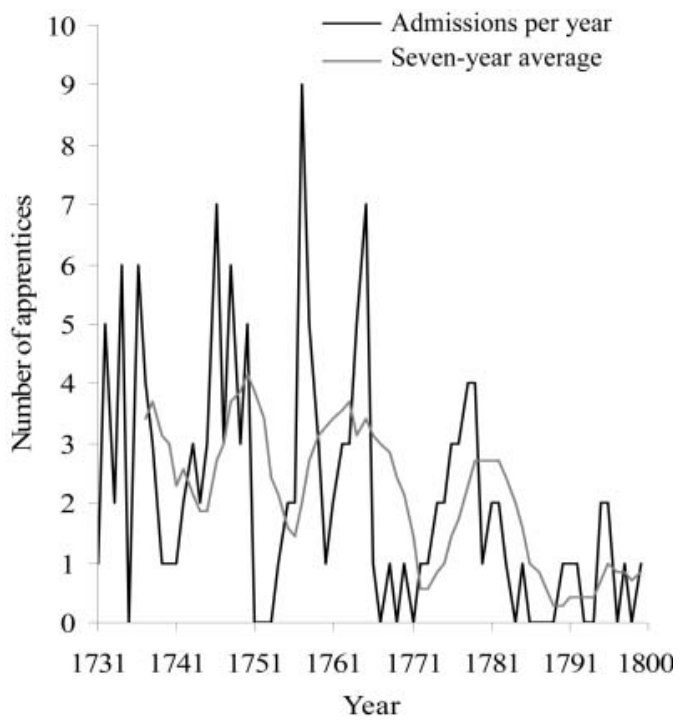

FIG. 3

Number of apprentices admitted to the London Horners' Company, 1731-1800 (based on Webb 1997). 18th century it rapidly lost its power. Sheffield became increasingly competitive and privileges which restricted competition were increasingly seen as unfair. By 1777 co-operative purchase of raw materials by the Horners' Company had ceased and the low rate of apprenticeships led to a gradual fall in the number of horners. ${ }^{27}$ The parish registers also reflect the industry's decline. After 1758, when the father's occupation in the Spitalfields baptism register was again recorded, not a single horner was mentioned and only one horn-turner, Joseph Berwick, who in 1785 lived in Dorset Street. $^{28}$

\section{INTERPRETATION OF HORNCORE-DOMINATED FAUNAL ASSEMBLAGES}

The zooarchaeological evidence for horners, tanners and butchers can be similar as their waste may include many cattle horncores. Large accumulations have been found at a number of postmedieval sites in the eastern parishes of London, where horners are known to have worked and where only a few tanners remained after most leather production had moved south of the river. Horncores sawn into sections distinguish hornworking from butchery and leather-working waste. The chopping of horncores at the base may reflect the work of tanners removing horn from the frontal bone for subsequent sale to horners. Sawn horncores, however, appear to be less common on tannery sites. 
In east London the geographical spread of cattle horncore accumulations (Fig. 5) resembles the known distribution of horners. Their location beyond the City walls shows that the 1455 order excluding malodorous workshops from the City was enforced. Archaeological work undertaken a century ago confirms this picture. ${ }^{29}$

In a study of cattle horncore accumulations, Armitage concluded that those dumped at Aldgate were probably waste from local slaughterhouses rather than from horners' preparation workshops. ${ }^{30}$ As many butchers worked near East Smithfield market, cattle horncores recovered at some of the sites could have come from their activities. However, many sites have yielded sawn horncores (Fig. 4). West interpreted the presence of sawn-off tips at the Royal Mint site as evidence of the law requiring cattle sold at East Smithfield to have two inches of the 'further [right] horn' sawn off to prevent the resale of livestock. ${ }^{31}$ This explanation is unlikely because living bone would have to have been dissected for the cut to be recognizable in the archaeological record. Horncore tips would have been sawn after the death of the animal by horners who wanted to accelerate the breakdown of the bonds between the horn and its core. It is possible, but less likely, that they might also have been cut by butchers preparing horn for sale to horners. The presence at Crispin Street of both horn sheets and sawn-off horncore tips suggests that the tips were usually cut on the horners' premises. Other sites have yielded only sawn body pieces left after the tips had been removed. However, the excavators may not have retrieved the small tips.
West demonstrated that 71 per cent of the horncores with tips sawn off at the Royal Mint were from the left side and argued that it reflected a true Englishman's insolence towards rules. ${ }^{32}$ An alternative interpretation could be that, once many of the right horn-tips had been removed at the market, the horner had more left horncores with complete tips to remove and did not need to take care in cutting into the horncore of a dead animal. These explanations may be unnecessary if McGrath is correct in believing that the requirement to remove horn-tips on sale was not respected..$^{33}$

Horncores sawn in the middle as well as at the base reflect the activities of horners. Butchers only needed to remove the core by cutting it at the base, whereas horn-workers required suitably sized pieces for use. The horncore samples at some sites are small, making it difficult to conclude which category of craftsman produced them. At other sites such as Crispin Street individual contexts vary with some containing many sawn horncores and others none.

\section{BUILDING MATERIAL}

The plentiful supply of horncores available where the trade was practised led to their reuse as a cheap alternative to bricks. In the 18th century cattle horncores were applied as a facing for earth walls:

[T] hey have ready to hand a multitude of the quicks or inner parts of ox-horns; for the outer part itself, is taken off and sold to

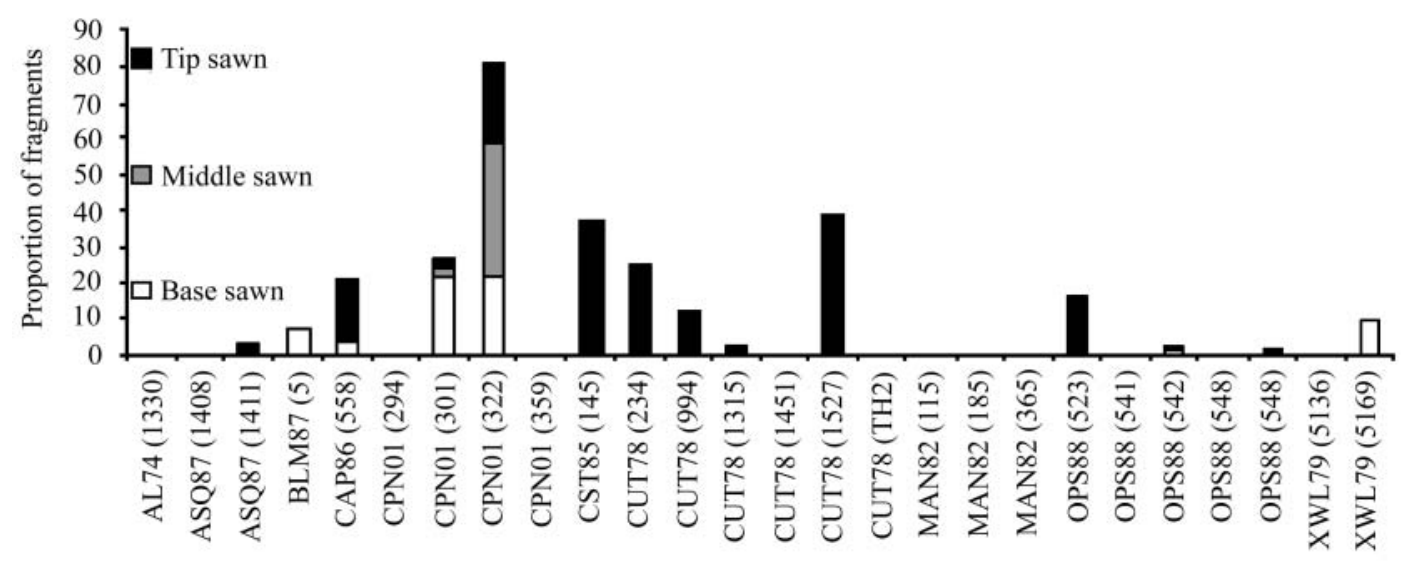

FIG. 4

London horncores: frequency of where sawn by site and context (from unpublished archive reports and re-examination of available collections at LAARC). AL74. 62-4 Aldgate High Street; ASQ87. America Square; BLM87. Bloomfield House; CAP86. Capel House; CPN01. Crispin Street; CST85. 6-7 Crescent; CUT78. Cutler Street; MAN82. 21-9 Mansell Street; OPS88. 158-64 Bishopsgate; XWL79. 8-10 Crosswall. 


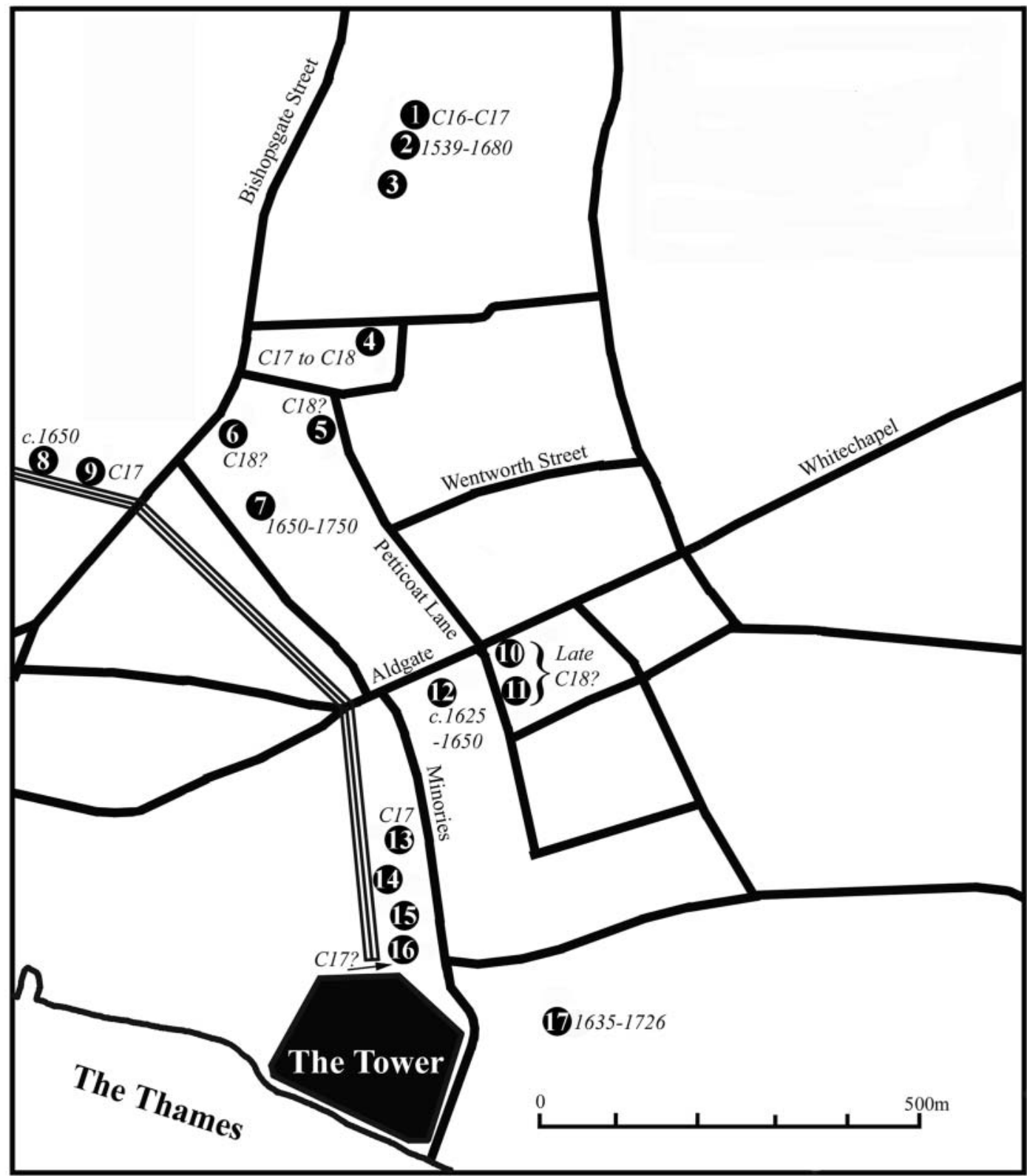

FIG. 5

Map of London's East End parishes locating sources of substantial collections of post-medieval cattle horncores with dates where known. 1. Spitalfields Market (SQU94); 2. Spitalfields (SRP98); 3. 250 Bishopsgate (STE92); 4. Crispin Street (CPN01); 5. 109-15 Middlesex Street (MSE88); 6. 158-64 Bishopsgate (OPS88); 7. Cutler Street (CUT78); 8. Capel House (CAP86); 9. Bloomfield House (BLM87). 10. Gardiner's Corner (GDC80); 11. 21-9 Mansell Street (MAN82); 12. 62-4 Aldgate High Street (AL74); 13. 8-10 Crosswall (XWL79); 14. America Square (ASQ87); 15. 8-11 Crescent (CRT89); 16. 6-7 Crescent (CST85); 17. Royal Mint (MIN86) (from unpublished archive reports at LAARC). 


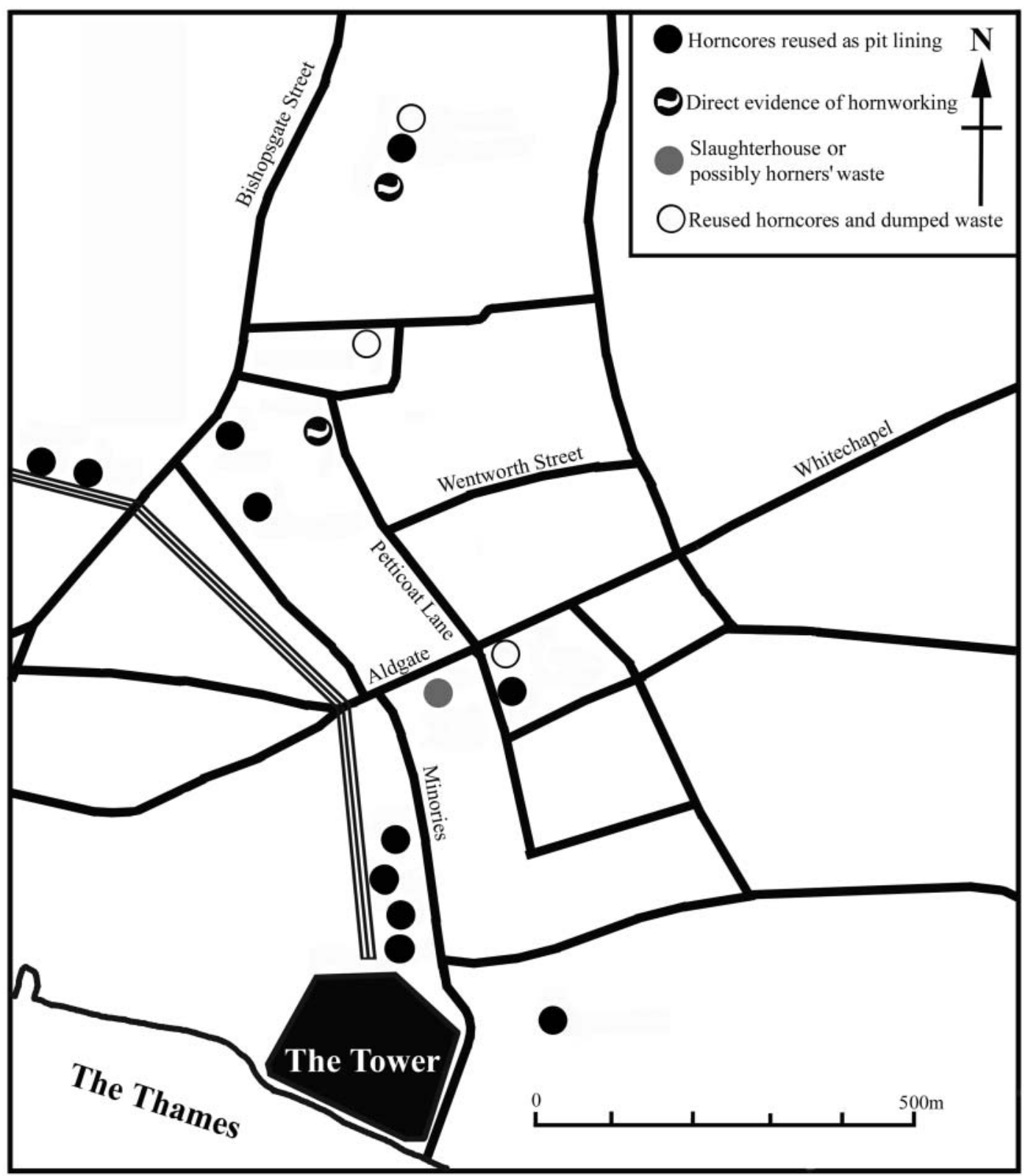

FIG. 6

Nature of London horncore assemblages shown in Fig. 5 (from unpublished archive reports, LAARC).

comb-makers and others who work in horn; or these have, after they have brought the whole horn from the butcher, retained the outerpart, and left the inner and useless part for this behoof. The quick is so cut off that part of the skull commonly goes with it. The quicks are then set quite close beside one another over the earth that has been upcast for the wall, and this so that the larger and thicker ends of the quick, or that to which a portion of the skull is attached, is turned outwards or lies just in the face of the side of the wall. In this way two rows of quicks are laid, viz.: one row on one side of the wall, and the 
other on the other, so that the small ends of the horns quicks meet in the middle. Over this is afterwards cast earth about six inches [150 mm] thick, when again in the aforementioned manner is laid a stratum of doubleranged ox-horn quicks ... The object of using the quicks is principally to bind the earth in the wall by them, and make it steady that it may not so soon slip down. ${ }^{34}$

Although walls of this kind have not yet been recorded, many pits lined with complete horncores have been excavated in east London, often in industrial contexts and in the waterlogged soils around the City ditch (Figs 5-6). For example, at Cutler Street ivory was worked, bells founded and glass made. Whereas some appear to be associated with metal casting (Fig. 5:7, 13), others were it seems cesspits, later filled with discarded chamber pots and other domestic refuse (Fig. 5:4, 12). They are also frequently found with other bricklined features. The uppermost courses of some horncore-lined pits were completed in brick.

It is unlikely that these pits were built to soak horncores. There is no evidence that horns had been soaked in them and they are much smaller than the soaking-pits excavated at York and Stamford. ${ }^{35}$ The distribution of horncore assemblages shows that those used to line pits predominate over horn waste dumps at greater distances from Petticoat Lane (Fig. 6). However, the parish registers reveal that the horn-working industry was more widespread. As the St Botolph Bishopsgate ones do not record occupation, we do not know whether or not the horners' waste reused around Houndsditch derived from workshops outside Bishopsgate, where horners had been active in the Middle Ages.

In more rural districts horncores were used to line field drains. ${ }^{36}$

\section{OTHER USES}

In the 19th century, after the horn sheath had been removed, the core was 'not thrown away, but burnt to constitute the bone earth used for the cupels for assaying gold and silver'. ${ }^{37}$ The porous horncore was easily reduced to ash and then made into crucibles. Bone ash absorbs lead oxides from ores, allowing droplets of precious metals to form.

In Sheffield during the 19th century horncores were dumped and at times recycled.

Bone nogs [horncores] appear at times to have been unsaleable, for it is related that at the end of Holly Street, on vacant land, a free tip was instituted, whereon cartloads of these nogs were deposited, but on their increasing value, they were recollected and put to commercial use. ${ }^{38}$

\section{CONCLUSIONS}

The characteristics of faunal horncore-dominated faunal assemblages can be used to deduce the trade which produced the waste. Most of the cattle horncore assemblages recovered in east London probably derived from nearby horn workshops. The distribution of their waste is consistent with the historical evidence for the location of horners. The paucity of sites on Petticoat Lane may reflect the lack of archaeological excavation. The waste may identify more precisely the workshops than the parish registers, whose information is limited to particular times and places. So far no archaeological site can be linked to a particular horner, but the written and material data sets complement each other to show where horn-working was practised in early modern London.

\section{ACKNOWLEDGEMENTS}

The research presented in this paper was funded by the Arts and Humanities Research Council and supervised by Dr Louise Martin and Dr Jane Sidell. Resources of the London Metropolitan Archive, the Guildhall Library and the London Archaeological Archive and Research Centre were utilized during the investigation.

\section{NOTES}

${ }^{1}$ Smith 1993, 4.

${ }^{2}$ Campbell 1747, 245.

${ }^{3}$ e.g. Ryder 1970; Cram 1982.

${ }^{4}$ Robertson 1989, 6.

${ }^{5}$ Curtis 1918, 38; Ekwall 1951, 24.

${ }^{6}$ Ekwall 1951, 24.

${ }^{7}$ Ekwall 1951, 24.

${ }^{8}$ Curtis 1918, 38; Ekwall 1951, 24.

${ }^{9}$ Fisher 1936, 117-19.

${ }^{10}$ GL MS 9220, MS 9222/2.

${ }^{11}$ LMA P93/MRY1/002-3, P93/MRY1/058-9.

${ }^{12}$ LMA P93/DUN/001, P93/DUN/128-9, P93/DUN/ 255-60, P93/DUN/275-281, P93/CTC1/001-03, P93/

CTC1/043-45.

${ }^{13}$ Fisher 1936, 74.

${ }^{14}$ GL MS 6535. 
${ }^{15}$ Yeomans 2007.

${ }^{16}$ LMA P71/MMG/008.

${ }^{17}$ LMA P71/OLA/014.

${ }^{18}$ LMA P71/JN/009.

${ }^{19}$ LMA P92/GEO/142.

${ }^{20}$ Fisher 1936, 122-6.

${ }^{21}$ LMA P93/MRY1/002.

${ }^{22}$ Webb 1997.

${ }^{23}$ Webb 1997, 1-33.

${ }^{24}$ Webb 1997.

${ }^{25}$ Walker 1986, 134.

${ }^{26}$ Fisher 1936, 52.

${ }^{27}$ Fisher 1936, 52.

${ }^{28}$ LMA P93/CTC1/002.

${ }^{29}$ To the east side of Jewry Street 'on what would have been outside the wall ... was the filling of a medieval ditch, composed of black mud and containing among other remains a large number of bullocks' horn', Norman \& Reader 1906, 194. The City ditch excavated at 15-16 America Square contained 16thcentury pottery and horncores, Norman \& Reader 1912, 304.

${ }^{30}$ Armitage 1984, 135.

${ }^{31}$ West 1995, 32.

${ }^{32}$ West 1995, 32.

${ }^{33}$ McGrath 1948, 159

${ }^{34}$ Kalm 1748, 69-70.

${ }^{35}$ Wenham 1960, 41; 1964, 25; Cram 1982, 48-51.

${ }^{36}$ Armitage et al. 1980, 413.

${ }^{37}$ Holtzapffel 2000, 7.

${ }^{38}$ Taylor $1927,8$.

\section{BIBLIOGRAPHY}

\section{PUBLISHED SOURCES}

Armitage, P. et al. 1980, 'Early agricultural field drains in the former parishes of Edmonton and Enfield', London Archaeol. 3, 408-15.

Armitage, P.L. 1984, 'The faunal remains', in Thompson et al. 1984, 131-43.

Brett-James, N.G. 1935, The Growth of Stuart London, London: London Middlesex Archaeol. Soc.

Campbell, R. 1947, The London Tradesman, London: David \& Charles.

Cram, L. 1982, 'The pits and horn cores', in Mahany et al. 1982, 48-51.

Curtis, M. 1918, 'The London Lay Subsidy of 1332', in Unwin 1918, 35-60.

Ekwall, E. 1951, Two Early London Subsidy Rolls, Lund: Gleerup.

Fisher, M.A. 1936, A Short History of the Worshipful Company of Horners, London: Horners' Company.

Holtzapffel, C. 2000, Working Horn, Ivory and Tortoiseshell, Portland: Caber Press.
Kalm, P. 1748, A Finnish Visitor to the Chilterns in 1748, Ashton Clinton: Kalm.

Mahany, C. et al. (eds) 1982, Excavations at Stamford, Lincolnshire, 1963-1969, Soc. Medieval Archaeol. Monogr. 9.

Norman, P. \& Reader, F.W. 1906, 'Recent discoveries in connexion with Roman London', Archaeologia 60, 169-250.

Norman, P. \& Reader, F.W. 1912, 'Further discoveries relating to Roman London, 1906-1912', Archaeologia 68, 258-344.

Pluskowski, A. (ed.) 2007, Breaking and Shaping of Beastly Bodies: Animals as Material Culture in the Middle Ages, Oxford: Oxbow.

Robertson, J.C. 1989, 'Counting London's horn cores: sampling what?', Post-Medieval Archaeol. 23, 1-10.

Ryder, M.L. 1970, 'The animal remains from Petergate, York, 1957-58', Yorkshire Archaeol. J. 42, 418-28.

Smith, L.P. 1993, 'Horn \& plastic - the natural connection', Plastiquarian 12, 4-5.

Taylor, W. 1927, The Sheffield Horn Industry, Sheffield: Northend.

Thompson, A. et al. 1984, 'Excavations at Aldgate, 1974', Post-Medieval Archaeol. 18, 1-148.

Unwin, G. (ed.) 1918, Finance and Trade under Edward III, Manchester: University Press.

Webb, C.R. 1997, London Apprentices 6, London: Society of Genealogists.

Wenham, L.P. 1960, 'The horners of Hornpot Lane, York', Trans. Yorkshire Dialect Soc. 60, 41-3.

Wenham, L.P. 1964, 'Hornpot Lane and the horners of York', Yorkshire Phil. Soc. Annu. Rep., 25-56.

West, B. 1995, 'The case of the missing victuals', Hist. Archaeol. 26, 20-42.

Yeomans, L. 2007, 'The shifting use of carcasses in medieval and post-medieval London', in Pluskowski 2007, 99-116.

\section{UNPUBLISHED SOURCES}

McGrath, P.V. 1948, 'The Marketing of Food, Fodder and Livestock in the London Area in the Seventeenth Century', University of London MA thesis.

Walker, M. 1986, 'The Extent of Guild Control in England c.1660-1820', University of Cambridge $\mathrm{PhD}$ thesis.

\section{ABBREVIATIONS}

GL Guildhall Library

LAARC London Archaeological Archive and Research Centre

LMA London Metropolitan Archive 


\section{SUMMARY IN FRENCH, GERMAN, ITALIAN AND SPANISH}

\section{RÉSUMÉ}

Données historiques et zooarchéologiques pour le travail de la corne dans le Londres post-médiéval La liste des membres de la Horners' Company (Société des fabricants de produits en corne) qui date de 1641, les registres de la paroisse et les documents relatifs aux apprentis offrent des informations sur l'emplacement de l'industrie du travail de la corne dans l'est de Londres, les relations familiales et le développement professionnel des fabricants de produits en corne. Les cornillons de bétail sciés permettent de distinguer les déchets du travail de la corne de ceux issus de boucheries et de tanneries. Les déchets de corne représentaient une alternative bon marché à l'utilisation de briques pour le revêtement des puits des ateliers d'autres artisans, des habitations et des conduits de drainage dans la campagne environnante.

\section{ZUSAMMENFASSUNG}

Historische und zooarchäologische Beweise für Hornverarbeitung im nachmittalterlichen London Die Mitgliederliste von 1641 der Horners' Company, Kirchenbücher und Lehrlingsrollen geben Informationen über die Standorte der Hornverarbeitung in Ost-London, über Familienbeziehungen und darüber, wie sich die Berufslaufbahn von Hornarbeitern entwickelt haben könnte. Gesägte Rinderhornkerne machen eine Unterscheidung zwischen Überresten der Hornverarbeitung und dem Abfall von Fleischer- oder Gerbereibetrieben möglich. Hornabfall wurde als billiger Ersatz für Ziegelsteine beim Auskleiden von Gruben in anderen Handwerksbetrieben und in Häusern verwendet, ebenso wie zum Auskleiden von Feldentwässerungsgräben in nahe gelegenen ländlichen Gebieten.

\begin{abstract}
RIASSUNTO
Documenti storici e zooarcheologici sulla lavorazione del corno nella Londra postmedievale L'elenco dei membri della Horners' Company di 1641, i registri parrocchiali e i ruolini degli apprendisti forniscono informazioni sull'ubicazione dell'industria della lavorazione del corno nei quartieri della Londra orientale, sui legami familiari e sul possibile sviluppo delle carriere in questo settore. Le corna bovine segate distinguono $\mathrm{i}$ depositi della lavorazione del corno da quelli degli scarti dei macellai e dei conciatori di pelli. Gli scarti delle corna venivano usati come sostituto a buon mercato dei mattoni per rivestire l'interno dei pozzi dei laboratori di altre attività commerciali e nelle case e anche per rivestire i condotti di scarico nelle vicine campagne.
\end{abstract}

\begin{abstract}
RESUMEN
Pruebas históricas y zooarqueológicas de objetos de asta en el Londres posmedieval

Gracias al estudio del listado de la Horners' Company, la Compañía de Trabajadores del Asta, de 1641, las actas parroquiales y los censos de aprendices, se ha podido localizar la existencia de industria ósea en asta en la zona oriental de Londres y se han estudiado las relaciones familiares y la forma en que pudiera haberse desarrollado la carrera de los trabajadores de esta industria. Los depósitos de la industria ósea se distinguen de los de carniceros y curtidores por la presencia entre los desechos de restos serrados del tejido esponjoso interior de las astas de ganado. Los desechos de las astas se usaban como sustituto barato del ladrillo para delimitar hoyos tanto en talleres de otros oficios como en viviendas, además de para mantener alineadas las zanjas de desagüe de las zonas de campo colindantes.
\end{abstract}

